\title{
EIROPAS MAKSĀJUMA RĪKOJUMS: SOLĪTAIS UN SKAUDRĀ REALITĀTE
}

\section{EUROPEAN PAYMENT ORDER: PROMISES AND SOBERING REALITY}

\author{
Inga Kačevska, Dr. iur. \\ Latvijas Universitātes Juridiskās fakultātes \\ Starptautisko un Eiropas tiesību zinātṇu katedras asociētā profesore
}

\author{
Baiba Rudevska, Dr. iur. \\ Zvērinātu advokātu biroja "BDO Legal" \\ vecākā juriste, ārštata konsultante
}

\section{Summary}

This article is based on a practical case study conducted in four Member States Germany, Portugal, Romania and Slovenia. The legal analysis has been implemented from the point of view of a Latvian creditor who goes to these four countries in order to start a European Payment Order procedure there. This article shows some real practical problems which occurred in aforementioned procedure. According to the authors, there are two types of problems: 1) those related to inappropriate application of the Regulation No.1896/2006; and 2) those related to application of different national procedural rules of Member States. Unfortunately, after ten years of applying of the Regulation it still fails to achieve its main purpose: to simplify, speed up and reduce the costs of litigation in crossborder cases concerning uncontested pecuniary claims. Consequently, the authors propose some possible legal and administrative solutions.

Atslēgvārdi: Eiropas maksājuma rīkojums, Regula Nr. 1896/2006, tiesu izdevumi, dokumentu izsniegšanas regula

Keywords: European Payment Order, Regulation No. 1896/2006, court fees, Service of Documents Regulation

\section{Ievads}

2006. gada 12. decembrī tika pieņemta Eiropas Parlamenta un Padomes Regula (EK) Nr. 1896/2006, ar ko izveido Eiropas maksājuma rīkojuma procedūru ${ }^{1}$ (turpmāk - Regula Nr. 1896/2006 vai regula), un to sāka piemērot no 2008. gada 12. decembra. Ir pagājuši desmit gadi kopš šîs regulas piemērošanas sākuma, tādēl tagad būtu îstais brīdis atskatīties uz tās darbību un izvērtēt, vai šo desmit gadu

1 Eiropas Parlamenta un Padomes Regula (EK) Nr. 1896/2006 (2006. gada 12. decembris), ar ko izveido Eiropas maksājuma rīkojuma procedūru. Eiropas Savienības Oficiālais Vēstnesis (turpmāk - OV), 30.12.2006., L 399, 1.-32. lpp. 
laikā ir sasniegti tās galvenie mērḳi: vienkāršot, paātrināt un samazināt tiesāšanās izdevumus pārrobežu lietās par neapstrīdētiem finanšu prasījumiem, kā arī izveidot vienotu ātru un efektīvu mehānismu, lai visā Eiropas Savienībā (turpmāk - ES) atgūtu neapstrīdētus finanšu prasījumus. ${ }^{2}$

Šajā rakstā autores izmantos prakses gadijumus, kuros Latvijas kreditors (ar Latvijā esoša pārstāvja starpniecību) iesniedza Eiropas maksājuma rīkojuma (turpmāk - EMR) pieteikumus četrās valstīs - Vācijā, Portugālē, Slovēnijā un Rumānijā. Visās šajās lietās kreditors minētajās valstīs piegādāja preces parādniekiem, kuri samaksu tā arī neveica. Saskaṇā ar Regulas Nr. 1215/2012 3 4. panta pirmo daḷu un 7. panta pirmās daḷas b) apakšpunkta otro ievilkumu visās norādītajās lietās starptautiskā jurisdikcija ir tām dalībvalstīm, ${ }^{4}$ kur atrodas atbildētājs (parādnieks) un kur piegādāja preci. ${ }^{5}$

Raksta struktūra atbilst divu konstatēto problēmu līmeņiem: 1) problēmas, kas izriet no regulas nepareizas piemērošanas, un 2) problēmas, kas saistītas ar ārpus regulas tiesisko regulējumu. Katrā no šìm daḷām autores apskatīs un analizēs praktiskās problēmas, kā arī piedāvās to risinājumus (galvenā pielietotā zinātniskā metode - indukcijas metode).

Diemžēl raksta l̦oti ierobežotā apjoma dēḷ tajā iespējams analizēt tikai dažas no autoru atklātajām daudzajām praktiskajām problēmām.

\section{Problēmas, kas izriet no Regulas Nr. 1896/2006 nepareizas piemērošanas}

Praktiskā situācija. Latvijā esošs prasītājs 2017. gada 19. decembrī kompetentajai Slovēnijas tiesai nosūtīja EMR pieteikumu. Par tā likteni prasītājs un viņa pārstāvis vairākus mēnešus neko nezināja. Tikai iesaistot Slovēnijas advokātu biroju, izdevās noskaidrot, ka Slovēnijas tiesā pieteikums saṇemts astotajā dienā pēc tā izsūtîšanas no Latvijas. Gandrīz septiṇus mēnešus pēc pieteikuma izsūtîšanas prasītāja pārstāvis no Slovēnijas tiesas beidzot saṇēma pirmo ziṇu - slovēṇu valodā sastādītu lēmumu par tiesvedības izbeigšanu, jo strīds neesot pakḷauts tiesai. Vienlaicīgi tiesa informēja, ka tā pārsūtījusi dokumentus "kompetentajai apgabaltiesai". 6

Slovēnijas tiesa šo savu slovēṇu valodā esošo lēmumu nosūtīja Latvijā esošam prasītājam un tā pārstāvim (katram atsevišķi ar piecu mēnešu starpỉbu), izmantojot Eiropas Parlamenta un Padomes Regulas (EK) Nr. 1393/2007 par tiesas un ārpustiesas civillietu vai komerclietu dokumentu izsniegšanu dalībvalstīs ("dokumentu izsniegšana”), ar ko atcel, Padomes Regulu (EK) Nr. 1348/20007 (turpmāk DIzR), 4. panta 3. punktā noteikto tiesas dokumentu pārsūtī̌anas kārtību tiesiskās

2 Regulas Nr. 1896/2006 mērḳi ir formulēti tās preambulas 9. un 29. apsvērumā, kā arī 1. panta 1. punktā.

3 Eiropas Parlamenta un Padomes Regula (ES) Nr. 1215/2012 (2012. gada 12. decembris) par jurisdikciju un spriedumu atzīšanu un izpildi civillietās un komerclietās. OV, 20.12.2012., L 351, 1.-32. lpp.

4 Vācijā EMR pieteikumus skata tikai viena tiesa - Berlīnes Vedingas rajona tiesa (Amtsgericht Wedding in Berlin - Europäisches Mahngericht Deutschland). Tas pats ir Portugālē - vienīgā tiesa ir Porto Komerctiesa (Juízo Central Cível do Tribunal da Comarca do Porto).

5 Sk. Regulas Nr. 1896/2006 6. pantu.

6 Sk. Slovēnijas tiesas 18.04.2018. lēmumu.

7 Eiropas Parlamenta un Padomes Regula (EK) Nr. 1393/2007 (2007. gada 13. novembris) par tiesas un ārpustiesas civillietu vai komerclietu dokumentu izsniegšanu dalībvalstīs ("dokumentu izsniegšana”) un ar ko atcel̦ Padomes Regulu (EK) Nr. 1348/2000. OV, 10.12.2007., L 324, 79.-120. lpp. 
palīdzības ceḷā. Salīdzinājumam: Vācijas, Portugāles un Rumānijas tiesas visus ar EMR procedūru saistītos dokumentus Latvijā esošam prasītājam sūtīja pa pastu (parasti ierakstītā vēstulē ar saṇemšanas apstiprinājumu, izṇemot Vācijas tiesu, kas izmanto vienkāršu pasta sūtījumu).

Saskaṇā ar Regulas Nr. 1896/2006 27. pantu regula neskar DIzR piemērošanu. Tas nozìmē, ka 27. pants saprotams kā norāde uz DIzR piemērošanu tiesas dokumentu izsniegšanas jautājumos. Pirmajā brīdī var šķist, ka DIzR nebūtu jāpiemēro, jo Regula Nr. 1896/2006 pati paredz minimālos standartus dokumentu izsniegšanā atbildētājam (sk. regulas 13.-14. p.). Taču gluži tā tas nav.

1) Regulas Nr. 1896/2006 13.-14. pantā noteiktie minimālie standarti nav uzskatāmi par tieši piemērojamām normām pārrobežu dokumentu izsniegšanā; tie tikai nosprauž noteiktu standartu. ${ }^{8}$

2) Regulas Nr. 1896/2006 13.-14. pantā ietvertajos minimālajos standartos ir norādīts, ka "EMR var piegādāt atbildētājam saskaņā ar tās valsts tiesību aktiem, kurā jāveic piegāde [..]”. DIzR nav minēta. Taču tas nenozīmē, ka tā nav piemērojama - arī DIzR 7. panta 1. punkts skaidri norāda uz "tās valsts tiesību aktiem, kurā jāveic piegāde”. Piemēram, spriedumā lietā C-21/17 Catlin Europe Eiropas Savienības Tiesa (turpmāk - EST) noteica, ka EMR atbildētājam jāizsniedz saskaṇā ar DIzR, vienlaicīgi ievērojot minimālos standartus. ${ }^{9}$

3) Minimālie standarti ir paredzēti tikai a) EMR izsniegšanai un b) tikai atbildētājam. Taču praksē EMR procesos tiesas dokumenti (vēstules, lēmumi, standarta veidlapas) ir jānosūta arī prasīājam. Jākonstatē, ka Regula Nr. 1896/2006 šo jautājumu vispār nerisina, un tādēḷ var uzskatīt, ka minimālie standarti neattiecas uz tiesas dokumentu izsniegšanu prasītājam. Šis jautājums ir atstāts vai nu dalībvalstu nacionālajiem likumiem (sk. Regulas Nr. 1896/2006 26. p.), vai DIzR (sk. Regulas Nr. 1896/2006 27. p.). Protams, ES civiltiesiskajā telpā pārrobežu tiesas dokumentu izsniegšanai piemērojama DIzR, ${ }^{10}$ kas ir pārāka par nacionālajiem likumiem. ${ }^{11}$ Turpretī, ja prasītājam vai atbildētājam dokumenti jāizsniedz tajā pašā valstī, kur notiek EMR process, tad piemērojami šìs dalībvalsts nacionālajās tiesībās noteiktie izsniegšanas noteikumi (attiecībā uz atbildētāju tie jākombinē ar Regulā Nr. 1896/2006 ietvertajiem minimālajiem standartiem).

4) Jāṇem vērā, ka DIzR paredz divu veidu dokumentu izsniegšanas mehānismus: a) tiesiskās palīdzības cel̦ā (4. p.) un b) izsniedzot tieši (12.-15. p.), ${ }^{12}$ tai skaitā izmantojot pasta pakalpojumus ${ }^{13}$ (14. p.).

\footnotetext{
${ }^{8}$ Rauscher T. (Hrsg.). Europäisches Zivilprozess- und Kollisionsrecht EuZPR / EuIPR: Kommentar. EG-MahnVO. Gruber U. P. (Art. 12). München: Sellier, 2010, S. 337; sk. arī EST 04.09.2014. spriedumu apvienotajās lietās C-119/13 un C-120/13 eco cosmetics, paras. 37, 43, kā arī: Kormann J. M. Das neue Europäische Mahnverfahren im Vergleich zu den Mahnverfahren in Deutschland und Österreich. Jena: JWV, 2007, S. 131-132.

9 EST 06.09.2018. spriedums lietā C-21/17 Catlin Europe, paras. 40, 48.

10 Rauscher T. 2010, S. 337.

11 Encyclopedia of Private International Law. Basedow J., Rühl G., Ferrari F., Pedro de Miguel Asensio (eds.). Vol. 2. Hau W., Service of Documents. Cheltenham: Edward Elgar Publishing, 2017, p. 1629.

12 Ibid.

13 Šādi saraksti veic un savus dokumentus sūta Portugāles, Vācijas un Rumānijas tiesas. Jāatzīmē, ka Vācijas tiesa sūta vienkāršā pasta sūtījumā (nevis ierakstītā vēstulē ar saṇemšanas apstiprinājumu, kā to paredz DIzR 14. p.).
} 
5) Attiecībā uz dažādu tiesas dokumentu izsniegšanu atbildētājam vai prasītājam tomēr būtu jāraugās uz izsniedzamā dokumenta veidu. Vissvarīgākais no tiem ir EMR, kura adresāts ir atbildētājs un kura piegādāšanas mehānismam veltīts Regulas Nr. 1896/2006 12. panta 5. punkts. Savukārt pārējiem tiesas dokumentiem (vēstulēm, rēḳiniem, procesuāliem lēmumiem) ir mazāk svarīga nozīme, tādēl to izsniegšanā nav jāievēro minimālie standarti un tos var piegādāt pasta sūtījuma veidā (DIzR 14. p.). Tā kā viens no Regulas Nr. 1896/2006 mērķiem ir procesa ātrums, tad pareizi izraudzìts dokumentu izsniegšanas veids ir l̦oti svarīgs, lai ietaupītu laiku.

Lìdz ar to Slovēnijas tiesai formāli bija tiesības nosūtīt savu lēmumu izsniegšanai Latvijā esošam prasītājam, izmantojot DIzR 4. pantā paredzēto mehānismu tiesisko palīdzību. Taču tiesa neṇēma vērā sava procesuālā lēmuma svarīguma pakāpi; tā šo dokumentu varēja sūtīt ar pasta starpniecību (DIzR 14. p.), tādējādi ietaupot laiku.

Rezultātā jāsecina, ka Regula Nr. 1896/2006 dokumentu pārrobežu izsniegšanā paredz diezgan sarežḡitu tiesisko mehānismu, kas no piemērotāja prasa ḷoti labas zināšanas tiesību normu interpretācijā (kombinējot divas regulas un valstu nacionālos likumus; ${ }^{14}$ sk. iepriekš). Šāda situācija ir uzskatāma par pārāk sarežğītu, kas praksē spēj izraisīt dažādas problēmas, ${ }^{15}$ kuras jau parādījās gan EST lietā C-21/17 Catlin Europe, gan arī aplūkotajā Slovēnijas tiesas gadījumā. Autores uzskata, ka, ņemot vērā iepriekš minēto, šo problēmu varētu atrisināt, padarot skaidrāku Regulā Nr. 1896/2006 esošo normatīvo regulējumu, un tādēḷ piedāvā 1. tabulā minētos grozījumus un papildinājumus.

\section{1. tabula. Regulas Nr. 1896/2006 papildinājumi}

\begin{tabular}{|c|c|}
\hline $\begin{array}{c}\text { Regulas Nr. 1896/2006 } \\
\text { pašreizējā redakcija }\end{array}$ & $\begin{array}{c}\text { Regulas Nr. 1896/2006 } \\
\text { piedāvātā redakcija }\end{array}$ \\
\hline $\begin{array}{l}\text { 12. panta 5. punkts } \\
\text { “5. Tiesa }{ }^{16} \text { nodrošina, ka rīkojumu } \\
\text { piegādā atbildētājam saskaņā ar valsts } \\
\text { tiesību aktiem, ievērojot minimālos } \\
\text { standartus, kas noteikti } 13 ., 14 \text {. un } \\
\text { 15. pantā." }\end{array}$ & $\begin{array}{l}\text { 12. panta 5. punkts } \\
\text { “5. Tiesa nodrošina, ka citā dalībvalstī esošam at- } \\
\text { bildētājam rīkojumu piegādā saskaņā ar Regulu } \\
\text { Nr. 1393/2007, bet tiesas valstī esošam atbildētā- } \\
\text { jam - saskan̄ā ar tiesas valsts tiesību aktiem. Abos } \\
\text { iepriekš minētajos gadījumos vienlaicīgi jāie- } \\
\text { vēro minimālie standarti, kas noteikti 13., 14. un } \\
\text { 15. pantā." }\end{array}$ \\
\hline
\end{tabular}

14 Par to sīkāk sk.: Rudevska B. Quality of Legal Regulation of Minimum Procedural Standards in European Procedures of Enforcement of Decisions: A Critical Analysis. In: The Quality of Legal Acts and its Importance in Contemporary Legal Space. Riga: University of Latvia Press, 2012, p. 629.

15 Sk.: Velicogna M., Lupo G., Ontanu E. A. Simplifying access to justice in cross-border litigation, the national practices and the limits of the EU procedures. The example of the service of documents in the order for payment claims, p. 26. Pieejams: https://ssrn.com [aplūkots 07.04.2019.].

16 Juridiskajā literatūrā notiek diskusija par to, ka formulējums “Tiesa nodrošina, ka rīkojumu piegādā atbildētājam [..]” praksē rada problēmas ar tām dalībvalstīm (piemēram, Franciju), kuru nacionālie likumi noteic, ka par tiesas dokumentu piegādāšanu atbildētājam ir jārūpējas prasītājam (nevis tiesai). Tas šajās dalībvalstīs sarežg̀ì, pagarina un sadārdzina EMR procesus. Tādēḷ autores no savas puses iesaka papildus apsvērt iespēju Regulas Nr. 1896/2006 12. panta 5. punktā iekḷaut arī grozījumu šādā redakcijā: "Tiesa piegādā rīkojumu atbildētājam [..]”, tādējādi autonomi uzliekot visu dalībvalstu tiesām šo EMR pieteikuma piegādes pienākumu. Par šo problēmu sīkāk sk.: Velicogna M., Lupo G., Ontanu E. A. Simplifying access to justice in cross-border litigation, the national practices and the limits of the EU procedures, pp. 19-22, 26-27, 31. 


\begin{tabular}{|c|c|}
\hline $\begin{array}{l}\text { 13. pants } \\
\text { "Eiropas maksājuma rīkojumu var pie- } \\
\text { gādāt atbildētājam saskaņā ar tās valsts } \\
\text { tiesību aktiem, kurā jāveic piegāde, iz- } \\
\text { mantojot vienu no šīm metodēm: } \\
\text { [..]" }\end{array}$ & $\begin{array}{l}\text { 13. pants } \\
\text { "Eiropas maksājuma rīkojumu citā dalībvalstī } \\
\text { esošam atbildētājam piegādā saskañā ar Regulu } \\
\text { Nr. 1393/2007. Ja atbildētājs atrodas valstī, kurāiz- } \\
\text { skata pieteikumu Eiropas maksājuma rīkojumam, } \\
\text { tad Eiropas maksājuma rīkojumu viņam piegādā } \\
\text { saskaņā ar tiesas valsts tiesību aktiem. Neatkarīgi } \\
\text { no atbildētāja atrašanās vietas valsts, piegāde vien- } \\
\text { laicīgi jāveic, izmantojot vienu no šīm metodēm: } \\
\text { [..]" }\end{array}$ \\
\hline $\begin{array}{l}\text { 14. pants } \\
\text { "Eiropas maksājuma rīkojumu var arī } \\
\text { piegādāt atbildētājam saskaņā ar tās } \\
\text { valsts tiesību aktiem, kurā jāveic piegā- } \\
\text { de, izmantojot vienu no šīm metodēm: } \\
\text { [..]" }\end{array}$ & $\begin{array}{l}\text { 14. pants } \\
\text { "Eiropas maksājuma rīkojumu citā dalībvalstī } \\
\text { esošam atbildētājam piegādā saskan̄ā ar Regulu } \\
\text { Nr. 1393/2007. Ja atbildētājs atrodas valstī, kurā } \\
\text { izskata pieteikumu Eiropas maksājuma rīkoju- } \\
\text { mam, tad Eiropas maksājuma rīkojumu viñam } \\
\text { piegādā saskan̄ā ar tiesas valsts tiesību aktiem. } \\
\text { Neatkarīgi no atbildētāja atrašanās vietas valsts, } \\
\text { piegāde vienlaicīgi jāveic, izmantojot arī vienu no } \\
\text { šīm metodēm: } \\
{[. . \text { ]" }}\end{array}$ \\
\hline \begin{tabular}{l}
\multicolumn{3}{c}{ 27. pants } \\
“Šì regula neskar Padomes Regu- \\
las (EK) Nr. 1348/2000 (2000. gada \\
29. maijs) par tiesas un ārpustiesas \\
civillietu un komerclietu dokumentu \\
izsniegšanu Eiropas Savienības dalīb- \\
valstīs piemērošanu."
\end{tabular} & $\begin{array}{l}\text { 27. pants } \\
\text { "1. Šī regula neskar Eiropas Parlamenta un Pa- } \\
\text { domes Regulas (EK) Nr. 1393/2007 (2007. gada } \\
\text { 13. novembris) par tiesas un ārpustiesas civillietu } \\
\text { un komerclietu dokumentu izsniegšanu dalībval- } \\
\text { stīs (“dokumentu izsniegšana"), ar ko atcel Pado- } \\
\text { mes Regulu (EK) Nr. 1348/2000, piemērošanu. } \\
\text { 2. Piegādājot citā dalībvalstī esošam atbildētājam } \\
\text { Eiropas maksājuma rīkojumu, piemēro Regulu } \\
\text { Nr. 1393/2007, vienlaicīgi ievērojot 13., 14. un } \\
\text { 15. pantā noteiktos minimālos standartus. } \\
\text { 3. Piegādājot citā dalībvalstī esošam prasītājam tie- } \\
\text { sas dokumentus, piemēro Regulu Nr. 1393/2007, } \\
\text { izvēloties pēc iespējas ātrāko dokumentu piegādes } \\
\text { veidu." }\end{array}$ \\
\hline
\end{tabular}

Vienlaikus jāatzīmē, ka ES institūcijas ir izstrādājušas priekšlikumu DIzR uzlabošanai, tajā paredzot veidus, kā ātrāk izsniegt dokumentus. ${ }^{17}$ Tā kā lielākā daḷa dokumentu prasītājam EMR procedūrā tiek sūtīti pa pastu (DIzR 14. p.), tad šajā kārtībā turpmāk paredzēti uzlabojumi: pasta pakalpojumu sniedzējiem, izsniedzot dokumentus pa pastu saskaņā ar DIzR, būs jāizmanto īpašs paziṇojums - apstiprinājums par saṇemšanu (kas būs iekḷauts jaunajā IV pielikumā). Paredzēta arī dokumentu elektroniskas izsniegšanas iespēja. ${ }^{18}$

17 Priekšlikums Eiropas Parlamenta un Padomes Regula, ar ko groza Eiropas Parlamenta un Padomes Regulu (EK) Nr. 1393/2007 par tiesas un ārpustiesas civillietu vai komerclietu dokumentu izsniegšanu dalībvalstīs (“dokumentu izsniegšana”). COM(2018)379 final, 31.05.2018.

18 Ibid. 


\section{Problēmas, kas saistītas ar ārpus Regulas Nr. 1896/2006 tiesisko regulējumu}

Šajā nodaḷā autores apskatīs dažas problēmas, kas saistītas ar jomām, kuras Regula Nr. 1896/2006 pati neregulē, bet atstāj valstu nacionālo tiesību ziṇā. Viena no tām ir ar tiesas izdevumu aprēḳināšanu un samaksu saistītā problemātika. Savukārt otrs problēmu loks ir saistīts ar dažādiem sarežǵījumiem, kas izriet no dalībvalstu nacionālo likumu īpatnībām.

Pirmā praktiskā situācija. Saskaṇā ar Regulas Nr. 1896/2006 25. panta 2. punktu šajā regulā tiesas izdevumi ietver nodevas un maksas, kuras maksājamas tiesai un kuru summa ir noteikta saskaṇā ar valsts tiesību aktiem. ${ }^{19} \mathrm{Kā}$ redzams, visus ar tiesas izdevumiem saistītos jautājumus regula atstāj dalībvalstu nacionālo procesuālo tiesību ziṇā (sk. arī regulas 26. p.). Tas nozīmē, ka attiecībā uz tiesas izdevumiem EMR procesos pastāv 27 dažādi tiesiskie regulējumi. Taču, pieteicējam iesniedzot citā valstī EMR pieteikumu, jautājumi par tiesu izdevumu apmēru, tiesu bankas kontiem, kuros iemaksājamas valsts nodevas, un maksāšanas kārtību (piemēram, ar pārskaitījumu, ar kredītkarti utt.) ir l̦oti aktuāli. Viņam ir jāapsver, cik maksās konkrētais EMR process.

Piemēram, praktiskajā rokasgrāmatā "Par Eiropas maksājuma rīkojuma procedūras regulas piemērošanu" teikts tikai tas, ka "nereti, iesniedzot attiecīgai tiesai pieteikumu, ir jāmaksā arī nodeva”. Tālāk dota saite uz e-tiesiskuma portālu (turpmāk - E-Justice $\left.{ }^{20}\right){ }^{21}$

Lai gan E-Justice ir paredzēts, ka visās ES oficiālajās valodās (arī latviešu) var atrast informāciju par valsts nodevu aprēḳināšanas kārtību, diemžēl autores to varēja atrast tikai par Vāciju, Rumāniju un Slovēniju, par kurām informācija sniegta attiecīgi tikai vācu, rumāṇu un slovēṇu valodā. Savukārt par Portugāli informācijas nav vispār. Piemēram, E-Justice par Rumāniju parādījās valsts nodevas aprēḳina mehānisms, kura rezultātā autores nonāca pie summas (1134,70 RON), kas nesakrita ar Rumānijas tiesas vēlāk norādīto valsts nodevas apmēru (200 RON). ${ }^{22}$

Tomēr ne tikai valsts nodevu aprēķināšanas kārtība sagādā problēmas E-Justice vietnē nekur nav paredzēta un tādēḷ nav atrodama informācija par tiesu banku kontiem, kuros jāieskaita valsts nodeva. Tādēl prasītājam nekas cits neatliek kā nosūtīt EMR pieteikumu un gaidìt ziṇas no ārvalsts tiesas. Praksē tiesu rīcība ir l̦oti dažāda. Piemēram, Vācijas gadỉjumā autores nosūtīja Berlīnes Vedingas rajona tiesai lūgumu sniegt informāciju gan par konkrētu valsts nodevas apmēru, gan arī banku rekvizītiem. Vācijas tiesa šādu informāciju atsūtīja. Taču sarakste ar tiesu prasīja papildu laiku - 22 dienas, kas neatbilst vienam no

19 Saskaņā ar Regulas Nr. 1896/2006 preambulas 26. apsvērumu “tiesas izdevumiem”, uz kuriem attiecas 25. pants, nebūtu jāietver, piemēram, advokātu honorārus vai tādas dokumentu piegādes izmaksas, ko veic cita iestāde, kura nav tiesa.

${ }^{20}$ E-Justice portāls. Pieejams: https://e-justice.europa.eu/

${ }^{21}$ Praktiskā rokasgrāmata "Par Eiropas maksājuma rīkojuma procedūras regulas piemērošanu“. Eiropas Komisija. Tieslietas. 2011, 17. lpp. Pieejams: https://e-justice.europa.eu/content_order_for_payment_ procedures-296-lv.do [aplūkots 03.02.2019.].

22 Ja pārvēršam prasības summu 4422,50 EUR Rumānijas lejās (RON), tad iegūstam 20 594,13 RON. Valsts nodeva ir 355 RON plus 5\%, kas pārsniedz 5000 RON. Formula 20 594,13 RON - 5000 RON = 15 594,13. 5\% no 15 594,13 RON = 779,70 RON + 355 RON = 1134,70 RON (aprēḳinātā un maksājamā valsts nodeva). Taču realitātē Rumānijas tiesa prasītājam noteica valsts nodevu 200 RON. 
regulas mērḳiem - paātrinātai procedūras norisei. ${ }^{23}$ Slovēnijas situācijā 1 gada un 3 mēnešu laikā EMR process vēl pat nav sācies (prasītājs nav informēts par valsts nodevas apmēru un tiesas bankas kontu). Līdzīgi ir ar Rumāniju - lai gan prasītājs beidzot ir uzzinājis valsts nodevas apmēru, viņam uz vairākiem pieprasijumiem sešu mēnešu laikā joprojām nav sniegta informācija par Bukarestes tiesas bankas kontu, kurā ieskaitāma šī summa. Savukārt Portugāles tiesas izrakstītais rēkinins (ar norādītu maksājuma mērḳi un kontiem) tika saņemts pa pastu vienkāršā vēstulē nedēḷas laikā no pieteikuma iesniegšanas dienas. Kā redzams, praksē vislabākā saziņa ir ar Vācijas un Portugāles tiesām. Turklāt tieši šajās abās valstīs, kur EMR pieteikumus skata viena konkrēta specializētā tiesa, process notiek ātrāk un profesionālāk. Attiecīgi Rumānijas un Slovēnijas tiesu rīcība vērtējama kā regulas mērķus pārkāpjoša, jo arī no EST sprieduma lietā C-215/11 Szyrocka ${ }^{24}$ izriet, ka ar tiesas izdevumu aprēḳināšanu saistītās procesuālās prasības (un arī tiesas de facto rīcība - autoru piezīme) nedrīkst izraisīt nedz pārmērīgi ilgu EMR procedūras pagarinājumu (Slovēnija, Rumānija), nedz arī pieteikuma šāda rīkojuma izdošanai noraidījumu (Rumānijā jau vairākas reizes, jo nav samaksāta valsts nodeva).

Pēc autoru domām, šeit varētu būt divi risinājumu virzieni (sk. 2. tabulu).

\section{2. tabula. Risinājumu virzienu izklāsts}

\begin{tabular}{|c|c|}
\hline Informācijas institucionāla centralizēšana & Informācijas leg̣islatīva centralizēšana \\
\hline $\begin{array}{l}\text { 1. Izveidot Eiropas tiesiskās sadarbības cen- } \\
\text { trus katrā no ES dalībvalstīm. Šādu ierosinā- } \\
\text { jumu } 2007 \text {. gada pētijumā par tiesu izmaksu } \\
\text { caurskatāmību civillietās ES izteica tā autori. } \\
\text { Minētie centri varētu ES iedzīvotāijiem sniegt } \\
\text { informāciju par ES dalībvalstu tiesību sistē- } \\
\text { mām. Informācijas ātru apmaiņu nodrošinātu } \\
\text { šo centru savstarpējā sadarbība informācijas } \\
\text { ieguvē."5 } \\
\text { Autores uzskata, ka šādi centri varētu tikt iz- } \\
\text { veidoti vai nu pie tieslietu ministrijām, vai pie } \\
\text { augstākajām tiesām, vai specializētajām EMR } \\
\text { tiesām (kā Vācijā un Portugālē). Tas darbotos } \\
\text { kā palīgorgāns E-Justice (kurā informācija ne- } \\
\text { tiek laikus ievietota; tā bieži ir vai nu noveco- } \\
\text { jusi, vai tās nav vispār, vai arī tā izlasāma tikai } \\
\text { attiecīgās dalībvalsts valodā, kuru persona } \\
\text { nesaprot). }\end{array}$ & $\begin{array}{l}\text { 1. Pašā Regulā Nr. } 1896 / 2006 \text { noteikt konkrē- } \\
\text { tu vienotu un nelielu tiesas izdevumu (valsts } \\
\text { nodevu) summu }{ }^{26} \text { (konkrētā summā vai } \\
\text { procentos no prasības summas) un izveidot } \\
\text { papildu pielikumu, kurā būtu norādīti tiesas } \\
\text { izdevumu samaksai paredzētie tiesu banku } \\
\text { konti katrā no dalībvalstīm. }\end{array}$ \\
\hline
\end{tabular}

${ }^{23}$ Sk. Regulas Nr. 1896/2006 preambulas 9. apsvērumu un 1. panta 1. punkta a) apakšpunktu.

${ }^{24}$ EST 13.12.2012. spriedums lietā C-215/11 Szyrocka, para. 35.

25 Study on the Transparency of Costs of Civil Judicial Proceedings in the European Union. Final Report. European Commission, 2007, p. 346.

${ }^{26}$ Eiropas Ekonomikas un sociālo lietu komiteja 2004. gadā izteica šādu priekšlikumu, taču regulā tas netika iestrādāts. Sk.: Eiropas Ekonomikas un sociālo lietu komitejas Atzinums par priekšlikumu attiecībā uz Eiropas Parlamenta un Padomes Regulu par maksājumu piedziņas procedūras iedibināšanu (COM(2004) 173 fina/3). OV, 08.09.2005., C 221, 77. lpp., 5.10.2. punkts. 


\begin{tabular}{|c|c|}
\hline Informācijas institucionāla centralizēšana & Informācijas leg̣islatīva centralizēšana \\
\hline $\begin{array}{l}\text { 2. E-Justice ievietot valsts nodevu aprēḳināša- } \\
\text { nas kalkulatoru par katru dalībvalsti. Vienlai- } \\
\text { kus ievietot informāciju par katras dalībvalsts } \\
\text { tiesu banku kontiem, kuros ieskaitāmas valsts } \\
\text { nodevas par EMR pieteikumu. } \\
\text { 3. Praktisko situāciju analīze Portugālē un } \\
\text { Vācijā liecina, ka vislabāk darbs ar EMR pro- } \\
\text { cesiem tiek organizēts valstīs, kurās EMR pie- } \\
\text { teikumus izskata tikai viena konkrēta tiesa. } \\
\text { Tādēl apsverama būtu arī EMR procesu dele- } \\
\text { gēšana vienai tiesai valstī. }{ }^{27}\end{array}$ & $\begin{array}{l}\text { 2. Regulā Nr. 1896/2006 izveidot divus atse- } \\
\text { višķus pielikumus: } \\
\text { 1) pielikumu ar informāciju par valsts no- } \\
\text { devām (to apmēriem, aprēkināšanu) katrā } \\
\text { dalībvalstī; } \\
\text { 2) pielikumu ar informāciju par katrā da- } \\
\text { lībvalstī esošiem tiesu banku kontiem, ku- } \\
\text { ros ieskaitāma valsts nodeva. } \\
\text { Taču vienlaikus jāspēj nodrošināt pieliku- } \\
\text { mos esošās informācijas aktualitāte. } \\
\text { 3. Regulā Nr. 1896/2006 paredzēt atteikšanos } \\
\text { no valsts nodevām par EMR pieteikuma ie- } \\
\text { sniegšanu. }{ }^{28} \text { Tas reizē varētu motivēt atbildē- } \\
\text { tājus izmantot EMR procedūru un samaksāt } \\
\text { parādu, negaidot pāreju uz sacīkstes tiesvedī- } \\
\text { bu, kurā no viniiem būtu piedzenami arī tiesas } \\
\text { izdevumi. }\end{array}$ \\
\hline
\end{tabular}

Otrā praktiskā situācija. Regulas Nr. 1896/2006 26. pants noteic, ka visus procesuālos jautājumus, kas nav konkrēti izklāstīti šajā regulā, reglamentē valsts tiesību akti. Savukārt 21. panta 1. punkts šo pašu nostāju precizē attiecībā tieši uz EMR izpildes procedūru, proti, izpildes procedūras reglamentē izpildes dalībvalsts tiesỉbu akti. Vienlaikus regula nosprauž tiesisko rāmi, pēc kura EMR izpilda ar tādiem pašiem nosacījumiem kā izpildāmos nacionālos lēmumus, ko izdevusi izpildes dalībvalsts. Tā kā minētie jautājumi tiek atstāti dalībvalstu nacionālo tiesību ziṇā, tie praksē prasîtājam mēdz izraisīt visnegaidītākās situācijas.

Darbā ar jau minētajām četrām valstīm autores saskārās ar virkni problēmu, kas saistîtas ar prasitājam iepriekš neparedzamu nacionālo tiesību normu piemērošanu. Viena no šādām situācijām EMR izpildes stadijā radās tieši Portugālē: lai varētu nodot izpildei EMR, tika prasîts, lai prasitāju pārstāvētu jurists. ${ }^{29}$ Konkrētajā lietā portugālu jurists par šādu pārstāvību prasija apmēram 1000 EUR plus izmaksas. Jāatgādina, ka kopējā prasības summa Portugālē bija 8316 EUR, no kuriem atbildētājs pēc EMR izdošanas labprātīgi samaksāja tikai daḷu, kā rezultātā palika 4362 EUR parāds. Kā redzams, par EMR 4362 EUR apmērā nodošanu piespiedu izpildei jurista pakalpojumi izmaksātu virs 1000 EUR, kas ir apmēram $1 / 4$ dala no piedzenamās summas. Pieteicējs, iesniedzot EMR pieteikumu, ar šādām izmaksām nevarēja rēḳināties. Arī E-Justice nav atrodama informācija par šādu

${ }^{27}$ Uz to savā pētījumā/publikācijā norāda arī: Velicogna M., Lupo G., Ontanu E. A. Simplifying access to justice in cross-border litigation, the national practices and the limits of the EU procedures, p. 31.

${ }^{28}$ Ibid., 5.10.1. punkts, kurā izteiktais līdzīgais priekšlikums skanēja šādi: "Ja nav iesniegts atbildes vai iebildumu raksts, Eiropas maksājumu piedziṇas procedūra tiek veikta bez maksas.”

${ }^{29}$ Fragments no Portugāles Tiesu izpildītāju profesionālās apvienības prezidenta elektroniskās vēstules: "The Portuguese Enforcement Agents could not initiate the procedures by themselves. To instruct the enforcement in Portugal (electronic compulsory), you must call for the services of lawyer or a Solicitor. Effectively, the Portuguese Enforcement Agents only perform the enforcement procedure (in an independent and impartial way), with the seizures of assets, credits, property's, bank accounts or values, judicial sails, and payments to the parties. Although, to instruct procedures that result from any foreign judicial decisions or European enforcement order, parties must always be represented by a Lawyer." 
izpildes īpatnību Portugālē. Turklāt EMR pieteikumā (A veidlapas 9. ailēên) šajā stadijā vairs nav iespējams iekḷaut juristu izmaksas, lai tās piedzìtu no atbildētāja (jo ir jau izdots izpildāms EMR par konkrētu summu).

Minēto problēmu varētu atrisināt, E-Justice iekḷaujot izsmeḷošu informāciju par izpildes procedūru īpatnībām katrā dalībvalstī, kā arī norādìt, kā šādos gadījumos prasītājs attiecīgajā valstī varēs atgūt šos izpildes stadijā maksājamos juristu honorārus. Otrs - daudz labāks - risinājums būtu regulas 21. panta 1. punktā iekḷaut papildu normu, kas dalībvalstīm aizliegtu EMR izpildes uzsākšanai prasìt obligātu jurista pakalpojumu izmantošanu: "Tomēr izpildes dalībvalsts nedrīkst atsaukties uz saviem nacionālajiem tiesību aktiem, lai prasītājam uzliktu par pienākumu izmantot jurista pakalpojumus nolūkā sagatavot prasītāja vēršanos kompetentajā izpildes iestādē šì panta 2. punktā noteiktajā kārtībā.”

Šāds aizliegums saskanētu ar 1) regulas preambulas 8. apsvērumu, pēc kura EMR procedūrai būtu jāgarantē vienādi noteikumi kreditoriem visā ES, un 2) vienu no regulas mērḳiem - tiesāšanās izdevumu samazināšanu.

\section{Secinājumi}

1. Viena no problēmām, kas saistīta ar Regulas Nr. 1896/2006 nepareizu piemērošanu, ir atsevišḳu dalībvalstu tiesu neprasme nošķirt šajā regulā noteiktos minimālos standartus no DIzR mehānisma. Tas izriet arī no nesenās EST judikatūras. Jāatzīst, ka šì problēma saistīta ar Regulas Nr. 1896/2006 neprecīzajām tiesību normām un to interpretācijas sarežgítību. Tādēl autores rakstā piedāvā atsevišḳu šìs regulas normu (12., 13., 14. un 27. p.) papildinājumus un grozijumus.

2. Nākamā problēmu grupa ir saistīta ar tiem gadījumiem, kurus Regula Nr. 1896/2006 atstāj dalībvalstu nacionālo tiesību zinā. Šajā grupā autores izškirir divas svarīgākās problēmas: 1) tiesas izdevumu (valsts nodevu) par EMR pieteikuma iesniegšanu aprēḳināšanu un samaksu; 2) dalībvalstu nacionālo procesuālo normu īpatnības, kuras citā valstī esošs prasītājs iepriekš nekādi nevar paredzēt.

3. Praksē nav iespējams savlaicīgi iegūt (un atsevišķos gadījumos tiesas konsekventi nesniedz) informāciju par valsts nodevu apmēriem un tiesu bankas kontiem, kuros iemaksājama šì nodeva. Šeit autores piedāvā risinājumus divos virzienos: 1) informācijas institucionālu centralizēšanu un/vai 2) informācijas leǵislatīvu centralizēšanu.

4. Darbā ar Portugāli EMR izpildes stadijā izrādījās, ka saskaṇā ar Portugāles nacionālo tiesisko regulējumu izpildei EMR var iesniegt tikai ar Portugāles jurista starpniecību. Tas prasītājam rada pēkšņus neparedzētus izdevumus. Pēc autoru domām, šìs problēmas risinājums varētu būt Regulā Nr. 1896/2006 iekḷaut papildu normu, kas dalībvalstīm aizliegtu EMR izpildes uzsākšanai prasīt obligāti izmantot jurista pakalpojumus.

5. Kopumā jāsecina, ka regulas galvenie mērḳi - vienkāršot, paātrināt un samazināt tiesāšanās izdevumus pārrobežu lietās - praksē joprojām netiek pilnībā sasniegti. Tādēl nākotnē ir nopietni jādomā par šì mehānisma uzlabošanu.

\footnotetext{
${ }^{30}$ Regulas Nr. 1896/2006 A veidlapas 9. ailē ("Izmaksas") lodziṇā 02 “cits” (tajā var iekḷaut prasītāja pārstāvja honorārus).
} 